\title{
Denervation of nerve terminals in renal arteries: one-year follow-up of interventional treatment of arterial hypertension
}

\author{
Krzysztof Bartuś ${ }^{1}$, Jerzy Sadowski ${ }^{1}$, Bogusław Kapelak ${ }^{1}$, Radosław Litwinowicz ${ }^{1}$, Wojciech Zajdel ${ }^{2}$, \\ Jacek Godlewski², Magdalena Bartuśs ${ }^{3}$, Krzysztof Żmudka², Anna Chrapusta ${ }^{4}$, Janusz Konstanty-Kalandyk², \\ Piotr Węgrzyn², Paul A. Sobotka ${ }^{5,6}$ \\ 'Department of Cardiovascular Surgery and Transplantology, Jagiellonian University, John Paul II Hospital, Krakow, Poland \\ 2John Paul II Hospital, Krakow, Poland \\ ${ }^{3}$ Department of Experimental Pharmacology, Jagiellonian University, Krakow, Poland \\ ${ }^{4}$ Ludwik Rydygier Hospital, Krakow, Poland \\ ${ }^{5}$ The Ohio State University, Columbus, Ohio, United States \\ ${ }^{6}$ Medtronic Inc., Santa Rosa, California, United States
}

\section{A bstract}

Background: Arterial hypertension is the most common cardiovascular system disease, affecting nearly one billion people worldwide. Despite the widespread use of antihypertensive medications, in some groups of patients an optimal blood pressure (BP) cannot be achieved.

Aim: To assess BP reduction in patients with resistant hypertension after a catheter-based renal sympathetic denervation procedure and to report vascular and kidney safety in one-year follow-up.

Methods: Twenty eight patients with diagnosed resistant hypertension (median age 52.02 years, range 42-72) underwent percutaneous catheter-based renal denervation of nerve terminals in renal arteries. Arterial angiography and procedure of ablation was performed by Symplicity catheters and generator provided by Ardian (currently Medtronic Inc., USA).

Results: Mean BP value before ablation was [mm Hg]: systolic 176.6, diastolic 100.28 and pulse pressure 73.4. After the procedure, reductions in the value of BP were reported [mm Hg]: systolic 154.8/152.54; diastolic 90.2/89.8, pulse pressure $64.66 / 62.73$, respectively in nine-month and one-year follow-up. All results were statistically significant. No complications during one year observation were observed.

Conclusions: Percutaneous renal artery ablation procedure effectively reduces systolic BP, diastolic BP, and pulse pressure. No vascular or renal complications in any of the patients were observed. The results of a Polish research group showed no significant differences compared to the results obtained in the international studies Symplicity I and Symplicity II.

Key words: arterial hypertension, renal related hypertension, resistant hypertension, renal arteries ablation

Kardiol Pol 2014; 72, 5: 425-431

\section{INTRODUCTION}

Hypertension remains a challenge for medicine in the $21^{\text {st }}$ century. One in three adults has hypertension, and more than half of people over the age of 65 suffer from it [1]. Unfortunately, with an ageing demographic shift, the prevalence of hypertension is expected to grow, and with it the morbidities and expenses associated with chronically elevated blood pressure (BP).

Despite the availability of hypotensive medications, more than $50 \%$ of patients fail to reach the recommended target BP of $<140 / 90 \mathrm{~mm} \mathrm{Hg}[1,2]$. Instructions to alter diet, increase exercise and efforts to improve persistence and

\section{Address for correspondence:}

Krzysztof Bartuś, MD, PhD, Department of Cardiovascular Surgery and Transplantology, Jagiellonian University, John Paul II Hospital, ul. Prądnicka 80, $31-202$ Kraków, Poland, tel: +48 1261430 75, fax: +48 1242339 00, e-mail: cool_chris@interia.pl Received: 05.07.2013 Accepted: 26.08.2013

Available as AoP: 17.12.2013

Copyright (C) Polskie Towarzystwo Kardiologiczne 
compliance with medications have not substantially improved the rates of treatment success. Whereas some of the treatment failures represent the decision of patients not to participate in lifelong lifestyle modification, with its required polypharmacy strategy, many patients have treatment-resistant hypertension that is linked to physiological resistance to pharmacological intervention. Regardless of the cause of treatment failure, the cardiovascular risk attributable to this elevated BP results in excess cerebral, cardiac, renal and peripheral vascular diseases. For that reason, an alternative treatment is needed.

Renal denervation (RD) is a non pharmacological strategy for treating hypertension that involves selective impairment of the nerves entering and leaving the kidney. Radical surgical sympathectomy has been performed in patients with persistent hypertension [3]. However, this operation brings surgical morbidity and complications which could be avoided.

Percutaneous catheter-based intraluminal selective sympathetic nerve ablation of renal arteries using radiofrequency (RF) has been performed without evidence of either vascular or renal injury and has proved to be an effective therapeutic intervention in patients with therapy-resistant hypertension whose elevated BP represents a cardiovascular hazard. Initial studies published in the Lancet in 2009 [4] (safety and proof of principle study) and in the Lancet in 2010 [5] (separate randomised controlled trial) using this method have been shown to successfully reduce BP without major adverse outcomes in patients with hypertension.

The aim of this study was to assess changes in arterial BP levels in patients after ablation of nerve terminals in renal arteries (denervation), as well as procedure safety in a one year follow-up of patients treated at a single Polish medical centre.

\section{METHODS}

Inclusion criteria for the patients were age 18-85 with a systolic BP above $160 \mathrm{~mm} \mathrm{Hg}$ despite compliance with three or more antihypertensive drugs (including diuretic). From all patients written informed consent was obtained. The study was approved by the Bioethics Committee at the Jagiellonian University in Krakow, Poland.

Excluded from the study were patients with known secondary hypertension, established renal failure, chronic kidney disease with glomerular filtration rate (GFR) $<35 \mathrm{~mL} / \mathrm{min}$ as well as those with renal artery disease or with anatomic contraindications to safe ablation (renal artery lumen diameter $<4 \mathrm{~mm}$, double or narrow renal arteries, critical stenosis). Other exclusion criteria are listed in Table 1.

All reported BP measurements were performed in triplicate, in a quiet room, when seated with back support and feet on the floor using an automatic device equipped with a recording printer for documentation - OMRON 7051T. The average of three measurements was used to qualify and assess the results.

The number of antihypertensive drugs taken by all patients ranged from three up to eight (average number of drugs 4.93). The number of antihypertensive drugs taken by study patients is shown in Figure 1.

Patients were treated with 14 different antihypertensive drugs and there was no benefit from specific drug analysis in the small group of patients.

Over the four weeks before therapeutic RD, in all subjects, mean BP value remained above $160 \mathrm{~mm} \mathrm{Hg}$, no modification of pharmacotherapy was allowed, and compliance with medication was verified by interview and patient

Table 1. Exclusion criteria

1. Renal arteries anomalies:

a. Haemodynamically significant renal artery stenosis (over $50 \%$ ) by visual assessment

b. Atherosclerotic lesion or stenosis within the artery which may potentially, according to the operator, add additional hazard to patient safety during artery catheterisation

c. Haemodynamically or physiologically significant stenosis which may be responsible for arterial hypertension

d. Prior renal artery stenting or angioplasty

e. Patients with more than one renal artery at one side

2. Suspicion of secondary hypertension or diagnosed secondary hypertension regardless of the underlying cause (including one associated with administered drugs)

3. Patients with a history of coronary artery disease manifested by myocardial infarction, unstable angina or stroke in the previous six months

4. Patients with significant valvular disease

5. Type 1 diabetes

6. Patients with an implantable cardioverter-defibrillator or pacemaker

7. Patients requiring breathing support

8. Patients suffering from a disease or taking drugs which may potentially influence the effectiveness of the therapy (e.g. peripheral atherosclerosis, aortic aneurysm, bleeding disorders, thrombocytopenia, anaemia, arrhythmia, alcohol abuse, drug addiction)

9. Patients who plan pregnancy or who are pregnant 


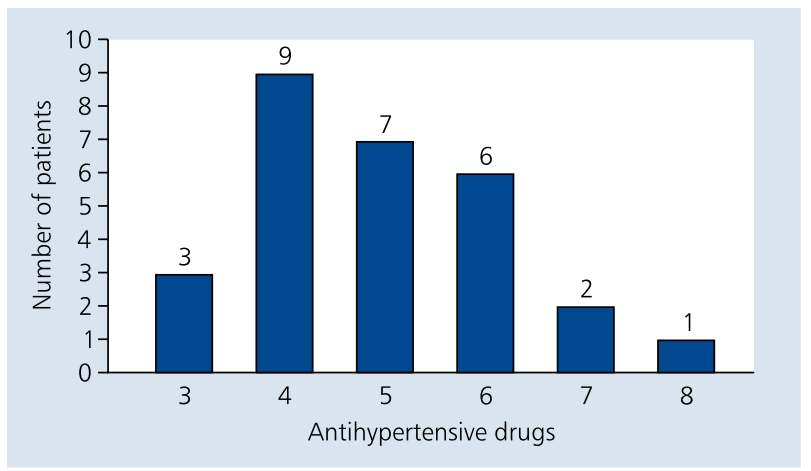

Figure 1. Number of antihypertensive drugs taken by all patients with resistant hypertension (mean 4.93 drugs)

diary. Patients underwent a systematic clinical monitoring for one year after the ablation procedure. Control tests were performed in the preoperative, three days postoperative, and after one, three, six, nine months and one year follow-up periods. History, physical examination, BP, blood tests and renal-function parameters were assessed at each follow up visit. Major adverse events, such as death, stroke, myocardial infarction or outcomes associated with the procedure itself (i.e. retroperitoneal bleeding, renal artery stenosis, access site complications) were monitored. No changes of pharmacological antihypertensive treatment were recommended during the entire research.

\section{Tested population}

Twenty-eight patients (16 males, 12 females) aged 42-72 (mean 52.02) with diagnosed arterial hypertension resistant to pharmacological treatment were identified and consented to therapeutic RD. The follow up procedures were assessed one, three, six, nine months and one year after the procedure. Patients' baseline characteristics are presented in Table 2.

The mean systolic BP values ranged from 160 to 212 (mean value 176.6) $\mathrm{mm} \mathrm{Hg}$, diastolic BP from 84 to 121 (mean value 100.28) $\mathrm{mm} \mathrm{Hg}$. The mean value for heart rate was $73.4 / \mathrm{min}$ (range from 60 to $98 / \mathrm{min}$ ). Apart for resistant hypertension, the coexisting cardiovascular diseases included: mild aortic valve stenosis (two patients), and coronary artery disease (nine patients). Of that group, two patients had suffered from myocardial infarction: one had percutaneous coronary intervention with stent implantation, and another had prior coronary artery bypass surgery. No patients had symptoms of peripheral artery disease. The other comorbidities included: hypercholesterolaemia (20 patients), diabetes mellitus type 2 (seven patients), peptic ulcer disease (three patients), asthma and chronic obstructive pulmonary disease (one patient). Only two patients were diagnosed with chronic renal insufficiency according to elevated creatinine and urea in blood serum.
Table 2. Baseline characteristics

\begin{tabular}{|lc|}
\hline Patient numbers & 28 (16 male, 12 female) \\
Age (mean) [years] & $42-72(52.02)$ \\
Height (mean) $[\mathrm{cm}]$ & $147-184(167.8)$ \\
Weight (mean) $[\mathrm{kg}]$ & $60-122(89.5)$ \\
Abdominal obesity (waist cir- & $6(21 \%)$ \\
cumference $>102 \mathrm{~cm}$ in men, & \\
$88>$ cm in women) & $20(71 \%)$ \\
Hypercholesterolaemia & $2(7 \%)$ \\
Current smoking & $1(3 \%)$ \\
Impaired glucose tolerance & $7(25 \%)$ \\
Diabetes mellitus type 2 & $9(32 \%)$ \\
Coronary artery disease & $3(10 \%)$ \\
Peptic ulcer & $1(3 \%)$ \\
Aortic stenosis & $1(3 \%)$ \\
Asthma, chronic obstructive & \\
pulmonary disease & $53.0-123.0(85.6)$ \\
Creatinine (mean) [ $\mu$ mol/L] & 1.8 \\
NYHA 1-3 - mean & 0 \\
Advanced retinopathy & 0 \\
Intermittent claudication & 0 \\
Stroke &
\end{tabular}

RD was performed in the standard endovascular technique via femoral artery using Symplicity catheters and generators delivered by Ardian Inc. (currently Medtronic Inc., USA). The catheter was advanced into both renal arteries. Six RF ablations lasting up to $120 \mathrm{~s}$ each with a maximum energy of $8 \mathrm{~W}$ or less were performed. A safe range of supplied energy and temperature measurement was made possible by the applied algorithm, specially programmed for the generator. During the procedure, heparin in a standard dose for renal angiography was used.

This paper is a sub-analysis of the patients recruited to the Symplicity study published in the Lancet in 2009 [4].

\section{Statistical analysis}

For statistical analysis, we assessed continuous variables between groups, including the primary endpoint, with Student's two-sample t test. We compared categorical variables with Fisher's exact test; for within group paired data, a paired t test was used. Two-sided alpha level of 0.05 was used for all superiority testing. All statistical analyses were done with Microsoft Office 2007.

\section{RESULTS \\ Periprocedural}

During and after the procedure, there were no significant adverse events in access vascular sites or renal, vascular and 
Table 3. Blood pressure changes, weight and heart rhythm changes; *data from [6]

\begin{tabular}{|c|c|c|c|c|c|c|}
\hline & Baseline & One month* & Three months* & Six months* & Nine months & One year \\
\hline$N$ & 28 & 21 & 26 & 26 & 28 & 26 \\
\hline $\begin{array}{l}\text { Systolic blood } \\
\text { pressure (mean) } \\
{[\mathrm{mm} \mathrm{Hg}]}\end{array}$ & $160-212(176.6)$ & $135-162(162.3)$ & $120-230(150.93)$ & $120-190(147.2)$ & $118-220(154.8)$ & $130-202(152.54)$ \\
\hline $\begin{array}{l}\text { Diastolic blood } \\
\text { pressure (mean) } \\
{[\mathrm{mm} \mathrm{Hg}]}\end{array}$ & $84-121(100.28)$ & $77-103(90.3)$ & $70-120(91.79)$ & $70-115$ (88.5) & 75-121 (90.2) & $72-117(89.8)$ \\
\hline $\begin{array}{l}\text { Pulse pressure } \\
\text { (mean) }[\mathrm{mm} \mathrm{Hg}]\end{array}$ & $56-100(76.57)$ & 52-93 (75.18) & $36-118(65.8)$ & $35-90(62.15)$ & $17-120(64.66)$ & $38-112(62.73)$ \\
\hline $\begin{array}{l}\text { Heart rhythm } \\
\text { (mean) [/min] }\end{array}$ & $60-98(73.4)$ & $60-80(72)$ & $52-100(74.39)$ & 56-104 (71.96) & $62-97(71.14)$ & $60-121(77.9)$ \\
\hline Weight (mean) [kg] & $60-120(89.5)$ & $72-120(89.22)$ & 71-105 (90) & $60-126(90.3)$ & 58-124 (91.11) & $68.5-122(88.14)$ \\
\hline
\end{tabular}

cardiovascular complications. Most patients reported diffuse visceral pain caused by the start of the ablation and ending with the cessation of ablation energy. Intravenous narcotic and sedative drugs were used for procedure-related pain control.

All patients were discharged directly home following the protocol requiring 2-5 days of hospitalisation. No complications related to the ablation procedure or adverse events were noted.

\section{One, three and six months follow-up}

The results of one, three and six months follow-up were very encouraging and have already been published in "Kardiologia Polska" 2013 [6].

\section{Nine months after the procedure}

Nine months after the procedure, 28 patients were seen in follow up. One patient modified prescribed medications and was excluded from the nine-month analysis. All other patients remained compliant with baseline pharmacotherapy.

There were no reports of adverse clinical events related to the procedure or BP changes.

The mean value of systolic BP for the 27 patients ranged from 118 to 220 (mean value 154.8) $\mathrm{mm} \mathrm{Hg}$ and was $21.8 \mathrm{~mm} \mathrm{Hg}$ lower than baseline (Table 3, Fig. 2). The mean value of diastolic BP for the 27 patients ranged from 75 to 121 (mean value 90.2) $\mathrm{mm} \mathrm{Hg}$ and was $10.09 \mathrm{~mm} \mathrm{Hg}$ lower than baseline before the ablation procedure. The pulse pressure decreased to $64.66 \mathrm{~mm} \mathrm{Hg}$ (mean value) from baseline 76.57 mm Hg (Table 3). Systolic BP, diastolic BP and pulse pressure were statistically significantly lower than at baseline.

The mean values of heart rate ranged from 62 to $97 / \mathrm{min}$ (mean value $71.14 / \mathrm{min}$ ) during the nine-month follow up. The mean heart rate was $2.27 / \mathrm{min}$ lower than that measured before the procedure (statistically not significant).

Urine samples tested nine months after the procedure were within standards. Baseline blood parameters did not

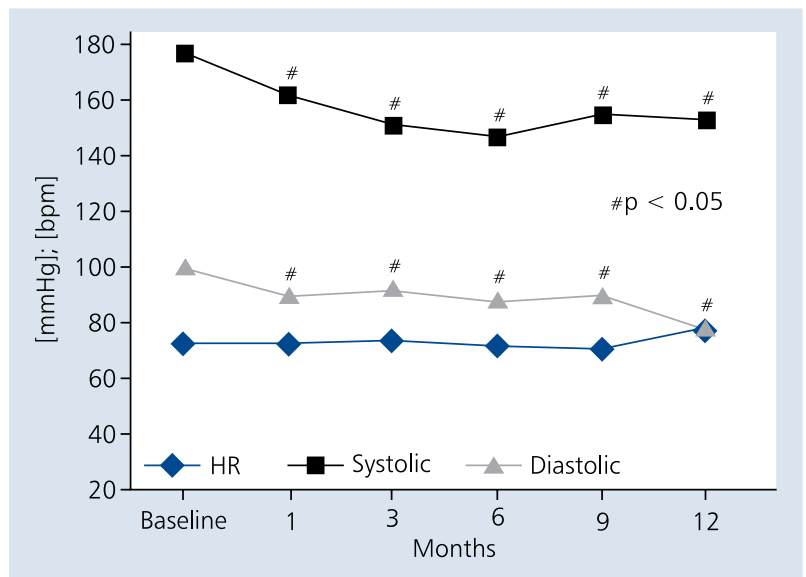

Figure 2. Mean systolic blood pressure, diastolic blood pressure and heart rate $(\mathrm{HR})$ baseline and one*, three*, six*, nine months and one year after the procedure; *data from [6]

reveal a rise in renal parameters used to detect for renal failure. The weight nine months after the procedure ranged from 58 to 124 (mean value 91.11) $\mathrm{kg}$ and was not statistically different from the mean value before the procedure.

\section{One year after the procedure}

One year after the procedure, 26 patients were seen in follow up. Three patients modified significantly prescribed hypertension medications and were excluded from the one year analysis. All other patients remained compliant with baseline pharmacotherapy.

The mean value of systolic BP for the 23 patients ranged from 130 to 202.3 (mean value 152.54) $\mathrm{mm} \mathrm{Hg}$ and was $24.06 \mathrm{~mm} \mathrm{Hg}$ lower than baseline (Table 3, Fig. 2). The mean value of diastolic BP for the 23 patients ranged from 72.33 to 116.66 (mean value 89.8) $\mathrm{mm} \mathrm{Hg}$ and was $10.48 \mathrm{~mm} \mathrm{Hg}$ lower than baseline before the ablation procedure. The pulse pressure decreased to $62.73 \mathrm{~mm} \mathrm{Hg}$ (mean value) from base- 
line 76.57 mm Hg (Table 3). Systolic BP, diastolic BP and pulse pressure were statistically significantly lower than at baseline.

The mean values of heart rate ranged from 60 to $121 / \mathrm{min}$ (mean value $77.9 / \mathrm{min}$ ) during the one year follow up. The mean heart rate was $4.48 / \mathrm{min}$ higher than that measured before the procedure (statistically not significant).

No complications related to the ablation procedure nor adverse events were noted.

Urine samples tested nine months after the procedure were within standards. Baseline blood parameters did not reveal a rise in renal parameters used to detect for renal failure. The weight nine months after the procedure ranged from 68.5 to 122 (mean value 88.14) kg and was not statistically different from the mean value before the procedure.

One year after the procedure in seven (30.4\%) patients, systolic BP was $\leq 140 \mathrm{~mm} \mathrm{Hg}$ and in 12 patients (more than $50 \%$ of all analysis patients) diastolic BP was $\leq 90 \mathrm{~mm} \mathrm{Hg}$. Optimum BP values $\leq 140 / 90 \mathrm{~mm} \mathrm{Hg}$ were observed in $17.4 \%$ of all patients.

Additionally, all patients had a computed tomography (CT) scan performed to check for renal artery lesions postoperatively. None of the patients who had a CT scan performed in either the six month or one year postoperative follow-ups had significant lesions in renal arteries diagnosed. Two patients had up to $30 \%$ lesions in their renal arteries, but these lesions had already been diagnosed during the preoperative angiography. No progress of any of these lesions was found in the one year follow up.

\section{DISCUSSION}

The results of our research are consistent with the result of a previous study. RF renal nerve ablation is both safe and effective in reducing the level of BP in patients with arterial hypertension resistant to pharmacotherapy. In the Polish sample, systolic BP, diastolic BP and pulse pressure were statistically significantly lower after the procedure, and the results were durable for at least one year.

At one year follow-up, the Symplicity I and Symplicity II trials showed that $84 \%$ of patients had durable lower BP. For Symplicity I, the mean decrease in systolic/diastolic BP was $25 / 11 \mathrm{~mm} \mathrm{Hg}$, and for Symplicity II it was $28.1 / 9.7 \mathrm{~mm} \mathrm{Hg}$ $(p<0.001)[7,8]$.

The results of the Polish research group are in line with a multicentre study [4]. In our group of patients, after one year of observation, RD led to $24.06 \mathrm{~mm} \mathrm{Hg}$ decrease in systolic BP, $10.48 \mathrm{~mm} \mathrm{Hg}$ decrease in diastolic BP, and $13.84 \mathrm{~mm} \mathrm{Hg}$ for pulse pressure which implies a substantial reduction of cardiovascular risk. $17.8 \%$ of patients achieved target BP $(\leq 140 / 90 \mathrm{~mm} \mathrm{Hg})$. In $30.4 \%$ of patients, systolic $\mathrm{BP}$ was $\leq 140 \mathrm{~mm} \mathrm{Hg}$ and in $52.1 \%$ of patients diastolic BP was $\leq 90 \mathrm{~mm} \mathrm{Hg}$. These results suggest that renal ablation with RF not only reduces the BP level, but also may lead to the elimination of the cardiovascular risk attributable to elevated BP.
The procedure was not associated with evidence of harm to the kidney (estimated GFR, serum creatinine level), urine test, lab test were unchanged from baseline to one year after procedure. This is particularly remarkable as the decline in BP and renal perfusion pressure was significant and renal function remained stable. This is different from the reduction of renal function often observed following pharmacologic therapy. To directly examine this observation, a trial observing renal function changes after similar declines in BP caused by RD and drug intervention needs to be performed.

The one year follow up revealed no new reports of renal failure, renal artery stenosis, or irregularity of BP regulation such as orthostatic hypotension. In several prior reports, cases of transient bradycardia, pseudoaneurysms at access site, rapid onset hypotonia, urinary tract infections, parestesia and pain have been observed during the procedure, but few long-term complications have been reported. Of all 205 patients from Symplicity I and II study who had RD, only one patient had mechanical complication caused by catheter guide (renal artery dissection) but there was no sequel [7, 8]. To date, no long-term vascular or renal complications have been reported [9]. These results, coupled with the similar findings of another study, confirm the absence of significant complications related to RD.

Some other data suggests that RD improves metabolic effects in women with polycystic ovary syndrome [10] and leads to improved glucose tolerance and sleep apnoea in hypertensive patients [11]. Other authors have also confirmed the improvement in glucose tolerance, which was not associated with modification of insulin or oral therapy [12].

The role of the afferent and efferent renal somatic and sympathetic fibres in hypertension pathogenesis is a well-known theory. The animal-model hypertension data showed major reduction level of noradrenaline in pigs undergoing renal ablation. This mechanism appears to be the main cause of the reduction in BP in humans treated with $\mathrm{RD}$. We should also mention the kidney's potential to regulate central sympathetic outflow [5, 13]. Renal afferents nerves ascend to the central nervous system (mainly to the hypothalamus), where they can cause functional changes and central sympathetic reaction.

According to this theory, RD may also be an effective method of treating other disorders associated with sympathetic hyperactivity like cardiovascular disease (i.e. heart failure, hypertrophic heart disease, ventricular hypertrophy, tachyarrhythmias, post myocardial ventricular dilation), chronic kidney disease, diabetes mellitus type 2 or polycystic ovary syndrome.

Preliminary results suggest that RF RD appears to be a safe, effective and practicable treatment to reduce BP in patients with treatment-resistant hypertension. It is assumed that the reduction of $\mathrm{BP}$ with $\mathrm{RD}$ will offer the same benefits as other strategies to reduce BP, although this remains to be 
demonstrated. Additionally, the value of RD in the treatment of less severe forms of hypertension or for the persistently non-compliant patient remains to be demonstrated. Importantly, the continued documentation of the safety and effectiveness of RD may offer an alternative to lifelong polypharmacy, and a solution for the patient who is failing pharmaco interventions. RD is currently being investigated for its utility in the treatment of other disorders linked to sympathetic hyperactivity — such as tachyatrial and ventricular arrhythmias, heart failure, and sleep disorders.

\section{CONCLUSIONS}

Percutaneous renal artery ablation procedure effectively reduces systolic BP, diastolic BP, and pulse pressure. No vascular or renal complications in any of the patients were observed. The results of a Polish research group showed no significant differences compared to the results obtained in the international studies Symplicity I and Symplicity II.

Conflict of interest: Paul A. Sobotka was medical director of Ardian Inc. and was consultant for Medtronic. No other conflicts are present.

\section{References}

1. Go AS, Mozaffarian D, Roger VL et al. Heart disease and stroke statistics: 2013 update: a report from the American Heart Association. Circulation. 2013; 127: e6-e245.

2. Wolf-Maier K, Cooper RS, Kramer H et al. Hypertension treatment and control in five European countries, Canada, and the United States. Hypertension, 2004; 43: 10-17.

3. Hoobler SW, Manning JT, Paine WG et al. The effects of splanchnicectomy on the blood pressure in hypertension: a controlled study. Circulation, 1951; 4: 173-183.
4. Krum H, Schlaich M, Whitbourn R et al. Catheter-based renal sympathetic denervation for resistant hypertension. A multicentre safety and proof-of-principle cohort study. Lancet, 2009; 373: 1275-1281.

5. Esler MD, Krum H, Sobotka PA et al. Renal sympathetic denervation in patients with treatment-resistant hypertension (the Symplicity Htn-2 Trial). A randomized controlled trial. Lancet, 2010; 376: 1903-1909.

6. Bartuś K, Sadowski J, Kapelak B et al. Denervation (ablation) of nerve terminalis in renal arteries: early results of interventional treatment of arterial hypertension in Poland. Kardiol Pol, 2013; 71: 152-158.

7. Symplicity HTN-1 Investigators. Catheter-based renal sympathetic denervation for resistant hypertension: durability of blood pressure reduction out to 24 months. Hypertension, 2011; 57: 911-917.

8. Esler MD, Krum H, Schlaich M et al. Renal sympathetic denervation for treatment of drug of drug-resistant hypertension: one-year results from the Symplicity HTN-2 randomized, controlled trial. Circulation, 2012; 126: 2976-2982.

9. Gewirtz JR, Bisognano JD. Catheter-based renal sympathetic denervation: a targeted approach to resistant hypertension. Cardiol J, 2011; 18: 97-102.

10. Schlaich MP, Hering D, Sobotka P et al. Effects of renal denervation on sympathetic activation, blood pressure, and glucose metabolism in patients with resistant hypertension. Front Physiol, 2012; 3: 10.

11. Witkowski A, Prejbisz A, Florczak E et al. Effects of renal sympathetic denervation on blood pressure, sleep apnea course, and glycemic control in patients with resistant hypertension and sleep apnea. Hypertension, 2011; 58: 559-565.

12. Schlaich MP, Hering D, Sobotka P et al. Effects of renal denervation on sympathetic activation, blood pressure, and glucose metabolism in patients with resistant hypertension. Front Physiol, 2012; 3: 10.

13. Schlaich MP, Sobotka PA, Krum H, et al. Renal sympathetic-nerve ablation for uncontrolled hypertension. N Engl J Med, 2009; 361: 932-934. 


\title{
Denerwacja zakończeń nerwowych w tętnicach nerkowych. Roczne wyniki interwencyjnego leczenia nadciśnienia tętniczego
}

\author{
Krzysztof Bartuś ${ }^{1}$, Jerzy Sadowski ${ }^{1}$, Bogusław Kapelak ${ }^{1}$, Radosław Litwinowicz ${ }^{1}$, Wojciech Zajdel ${ }^{2}$, \\ Jacek Godlewski², Magdalena Bartuśs ${ }^{3}$, Krzysztof Żmudka², Anna Chrapusta ${ }^{4}$, Janusz Konstanty-Kalandyk², \\ Piotr Węgrzyn"2, Paul A. Sobotka ${ }^{5,6}$
}

${ }^{1}$ Klinika Chirurgii Serca, Naczyń i Transplantologii, Szpital im. Jana Pawła II, Kraków

${ }^{2}$ Szpital im. Jana Pawła II, Kraków

${ }^{3}$ Katedra Farmakologii, Zakład Farmakologii Doświadczalnej, Kraków

${ }^{4}$ Szpital Uniwersytecki im. Ludwika Rydygiera, Kraków

${ }^{5}$ The Ohio State University, Columbus, OH, Stany Zjednoczone

${ }^{6}$ Medtronic Inc., Santa Rosa, California, Stany Zjednoczone

\section{Streszczenie}

Wstęp: Nadciśnienie tętnicze jest najczęstszym schorzeniem układu sercowo-naczyniowego, na które cierpi niemal 1 mld osób na świecie. Mimo powszechnie stosowanej farmakoterapii u części chorych nie udaje się uzyskać prawidłowych wartości ciśnienia tętniczego.

Cel: Celem pracy była ocena redukcji ciśnienia u pacjentów z lekoopornym nadciśnieniem tętniczym poddanych procedurze przezskórnej ablacji zakończeń nerwowych w okolicy tętnic nerkowych, a także ocena bezpieczeństwa wykonanej procedury w czasie rocznej kontroli pooperacyjnej.

Metody: Procedurze przezskórnej ablacji zakończeń nerwowych w okolicy tętnic nerkowych poddano 28 osób ze zdiagnozowanym nadciśnieniem tętniczym opornym na farmakoterapię (śr. wieku 52,02 roku, zakres 42-72 lat). W celu wykonania procedury i angiografii tętnic nerkowych użyto cewnika Symplicity firmy Ardian (obecnie Medtronic, USA).

Wyniki: Średnie wartości ciśnienia tętniczego przed procedurą wynosiły [mm Hg]: skurczowe 176,6; rozkurczowe 100,28; średnie ciśnienie tętna 73,4. Po wykonanej procedurze w 9-miesięcznej i rocznej kontroli pooperacyjnej odnotowano niższe średnie wartości ciśnienia tętniczego wynoszące odpowiednio [mm Hg]: skurczowe 154,8/152,54; rozkurczowe 90,2/89,8; średnie ciśnienie tętna 64,66/62,73. Wszystkie wyniki były znamienne statystycznie. Nie zaobserwowano istotnych powikłań w trakcie rocznej obserwacji.

Wnioski: Procedura ablacji tętnic nerkowych powoduje skuteczną redukuję średnich wartości skurczowego i rozkurczowego ciśnienia tętniczego, a także ciśnienia tętna. Nie zaobserwowano istotnych powikłań naczyniowych i nerkowych u żadnego z pacjentów. Wyniki polskiej grupy badawczej nie wykazują znaczących różnic w porównaniu z rezultatami uzyskanymi w międzynarodowych badaniach Symplicity I i Symplicty II.

Słowa kluczowe: nadciśnienie tętnicze, nadciśnienie nerkopochodne, oporne nadciśnienie, ablacja tętnic nerkowych

Kardiol Pol 2014; 72, 5: 425-431 